\title{
DEVELOPMENT OF THE CONVERSION VALUE FOR PERMEABILITY, ABSORPTION IN CONCRETE
}

\author{
Jonbi $^{1,}$ a , A.R. Indra Tjahjani ${ }^{1, b}$ F.X. Ferry Munaf ${ }^{1, c}$ \\ ${ }^{1}$ Civil Engineering, Faculty of Engineering, Pancasila University, Indonesia

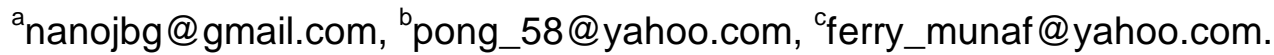

\begin{abstract}
Keywords: Permeability, absorption, compressive strength, and the conversion value.
\end{abstract}
Abstract:The development of construction technology today, allowing construction of high-rise building that has 20 floors or more simply the floor 5-7 cycles /day, so the time of completion of construction of the building quickly. The implication aspects of cost control, quality, time should be more strict and quick in decision making. One of the critical factors of success achieved work-storey building is the decision of determining material to be used. To besment whether using normal concrete (without admixture) or integral concrete waterproofing. Therefore it is necessary to use parameters or standards. Permeability, absorption and compressive strength of concrete. Standard generally used for permeability, absorption and compressive strength of concrete at the time was 28 days. Determination of the age of 28 days is often a problem that resulted in delays in the on going work. One of the parameters that is needed is the conversion value that can be used on the job besment, thus making receipt of material at an early age concrete. This study is very significant to generate the conversion value of permeability, absorption and compressive strength of normal concrete for concrete compressive strength: $f^{\prime} \mathrm{c} 30 \mathrm{MPa}, 35 \mathrm{MPa} f^{\prime} \mathrm{c}, f^{\prime} \mathrm{c} 40 \mathrm{MPa}, 45 \mathrm{MPa} f^{\prime} \mathrm{c}$ and $f$ 'c $50 \mathrm{MPa}$, so it can be used as a standard in determining the material used.

\section{Introduction}

Construction of buildings in Indonesia, especially big cities such as Jakarta, Surabaya, Medan, and so increased as shown in figure 1 high-rise building with over 20 floors, generally have 2-3 besment used for parking floor. The work has a high building floors 5-7 cycles / day, requiring cost control, quality and a good time, in order to achieve success in its development.

The main problem of high rise building construction jobs are on the job besment the frequent occurrence of leaks in floor and wall besment. Besment impact in a number of high-rise buildings can not be used due to a leak, it is very detrimental to the owner. One effort to overcome these problems by using Integral waterproofing admixture instead waterproofing membrane type, to overcome leakage. But the reality in the implementation of work until now is still a barrier for quality acceptance testing is done through permeability, and absorption at the time the concrete was 28 days. You can imagine the time wasted if waiting 28 days, while the work of the stakeholders to start to worry if the concrete has been applied at least 4-5 floors, it was the quality of the concrete can not be accepted, it becomes a dilemma.

Faced with this problem Stakeholder building, is in need of innovation related to acceptance of quality standards testing of concrete to be used can be faster, but can be accounted for.

Research on compressive strength of concrete with concrete age has been done, while research on the relationship with the compressive strength of concrete permeability and absorption is still very limited. As for knowing a watertight concrete or can not be seen from the value of the permeability and absorption. But unfortunately the problem has not received serious attention from researchers.

This gives opportunities and motivate researchers to produce a conversion rate of permeability, absorption in normal concrete and concrete with integral waterproofing for compressive strength of f'c: $30 \mathrm{MPa}, 35 \mathrm{MPa}, 40 \mathrm{MPa}, 45 \mathrm{MPa}$ and $50 \mathrm{MPa}$, so it can be used as parameters for decision-making. 


\section{Materials and Methodology}

The methodology used in this study is divided into two stages:

The first stage: make specimen for the normal concrete made on one of the readymix, this is done so that this research can be applied in the field. Preparation of test complete specimen can be seen in Table 1.

Table 1 Number of samples

\begin{tabular}{|c|c|c|c|c|c|c|c|c|c|c|}
\hline \multirow[t]{2}{*}{$\begin{array}{l}\text { Compreassive } \\
\text { strength } \\
\left(f^{\prime}{ }_{\mathrm{c}}\right)\end{array}$} & \multicolumn{3}{|c|}{$\begin{array}{l}\text { Size of cylinder } \\
15 \mathrm{~cm} \mathrm{x} 30 \mathrm{~cm}\end{array}$} & \multicolumn{3}{|c|}{$\begin{array}{l}\text { Permeability } \\
\text { The sample size of the } \\
\text { cube }(20 \times 20 \times 12) \mathrm{cm}\end{array}$} & \multicolumn{3}{|c|}{$\begin{array}{c}\text { Absorption } \\
\text { cylinders: } 7,5 \times 7,5 \\
\mathrm{~cm}\end{array}$} & \multirow[t]{2}{*}{$\begin{array}{l}\text { Total } \\
\text { Sample }\end{array}$} \\
\hline & I & II & III & I & II & III & I & II & III & \\
\hline 30 & 2 & 2 & 2 & 2 & 2 & 2 & 2 & 2 & 2 & 18 \\
\hline 35 & 2 & 2 & 2 & 2 & 2 & 2 & 2 & 2 & 2 & 18 \\
\hline 40 & 2 & 2 & 2 & 2 & 2 & 2 & 2 & 2 & 2 & 18 \\
\hline 45 & 2 & 2 & 2 & 2 & 2 & 2 & 2 & 2 & 2 & 18 \\
\hline 50 & 2 & 2 & 2 & 2 & 2 & 2 & 2 & 2 & 2 & 18 \\
\hline
\end{tabular}

The second stage: Stage of testing

Compressive strength testing of concrete cylinders in accordance with the size of $15 \times 30 \mathrm{~cm}$ SNI 03-1974-1990 standards for concrete at ages 1,3,7, and 28 days. The tools used Universal Testing Machine (UTM) $3000 \mathrm{KN}$ capacity.

Permeability test according to DIN $1048^{[1]}$ and ASTM C642-06, this test specimen that is, given a pressure of $5 \mathrm{~kg} / \mathrm{cm}^{2}$ for 3 days, after which the specimen is cleaved and measured water into concrete Absorption test according to the standard BS 1881 Part $122^{[2}$ ] testing done with test specimens were dried using an oven at a temperature of $105 \pm 5^{\circ} \mathrm{C}$ for $72 \pm 2$ hours. After the specimen is removed and left for 24 hours, then weighed. Furthermore, the specimen is immersed for 30 minutes, and weighed again.

Table 2 Mix Design of Concrete

composition

compressive strength of concrete (MPa)

\begin{tabular}{lrrrrr}
\cline { 2 - 5 } & 30 & 35 & 40 & 45 & 50 \\
\hline Semen type I $(\mathrm{kg})$ & 333 & 366 & 412 & 459 & 478 \\
\hline Fly ash & 59 & 65 & 73 & 81 & 75 \\
\hline Agregat Halus & 610 & 684 & 634 & 589 & 641 \\
\hline Agregat kasar & 1040 & 1037 & 1038 & 1012 & 1092 \\
\hline Air & 180 & 190 & 189 & 195 & 143 \\
\hline Rasio air semen & 0,46 & 0,44 & 0,39 & 0,36 & 0,3 \\
\hline Admixture & 0,96 & 1,10 & 1,44 & 3,67 & 3,25
\end{tabular}

\section{Results And Discussion}

Based on the results obtained by conversion value for the permeability of concrete fc as shown in figure 1. for compressive strength of $f^{\prime} \mathrm{c} 30 \mathrm{MPa}, 35 \mathrm{MPa}, 40 \mathrm{MPa}, 45 \mathrm{MPa}$ and $50 \mathrm{MPa}$ As for the conversion value of the absorption for concrete as shown in figure 2. 


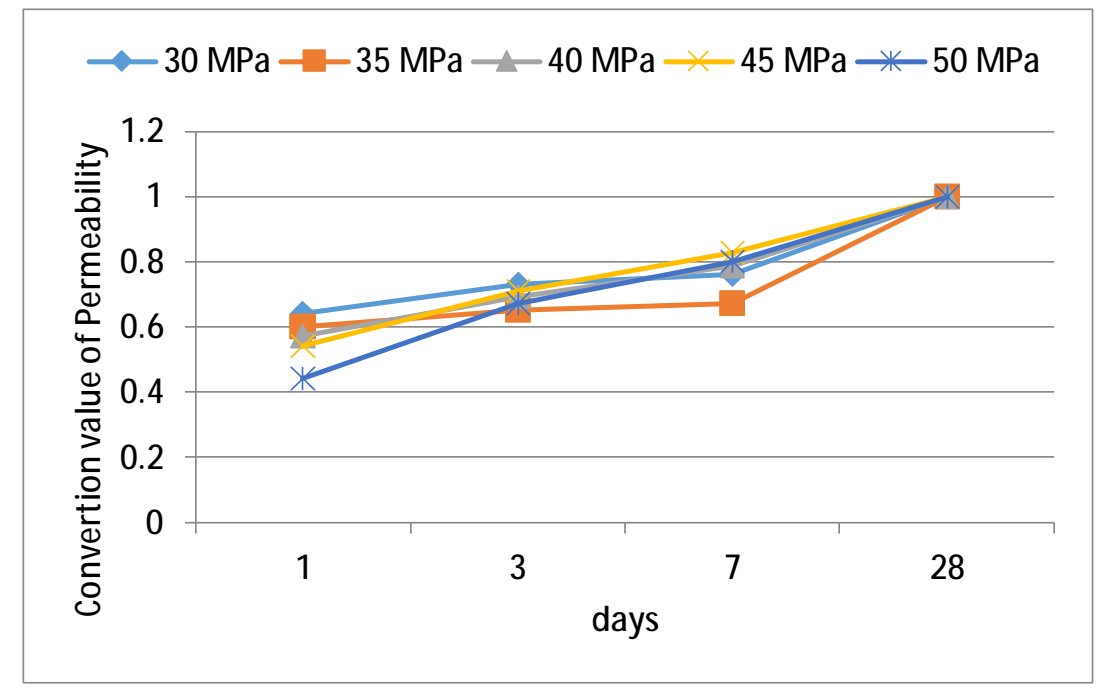

Fig. 1: Convertion value of permeability

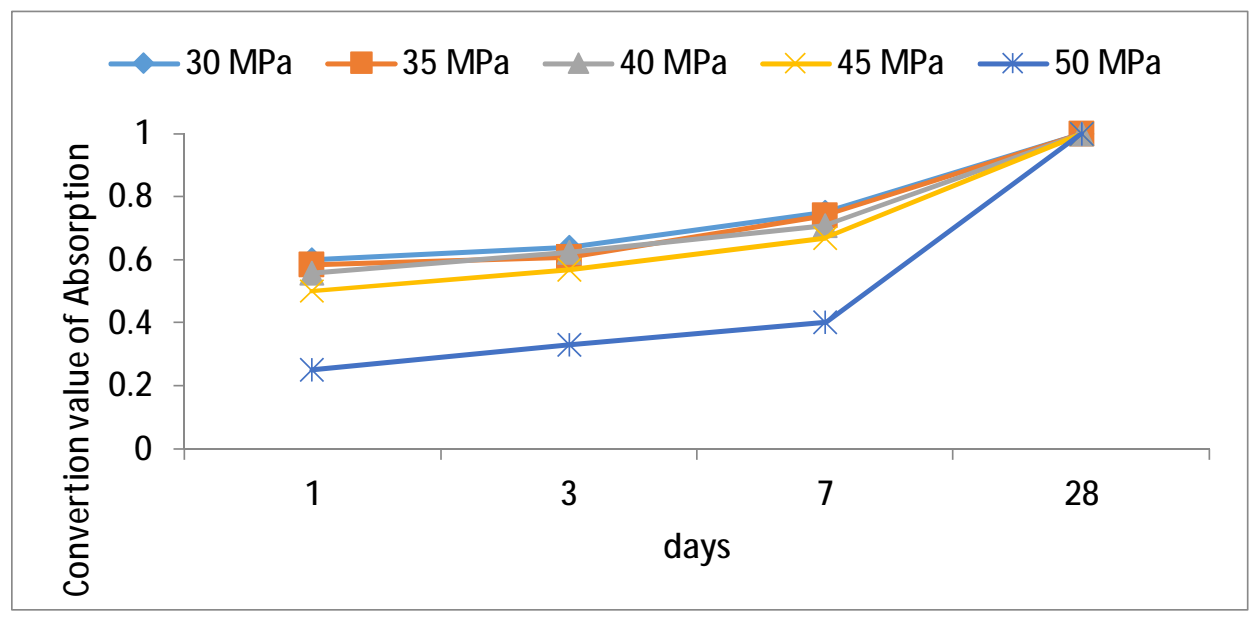

Fig. 2: Convertion value of Absorption

Based on the graph in Figure 1 and Figure 2, it can be seen the value of the conversion to permeability and absorption at the early age so that they can decide the use of concrete without having to wait for testing at 28 days.

\section{Conclusion}

Conversion value generated at the early age can be used to determine the permeability and absorption values at 28 days

\section{References}

[1] German Standard DIN 1048-Part 5 Section 3.6 1991. Testing Concrete Water permeability.

[2] British Standar Institution, BS 1881-122: 1983 (1983). Testing Concrete-Method for Determination of water absorption. London.

[3] Shamsad Ahmad et al, (2008), "Correlation between Depth of water penetration, Chloride Permeanility, and Coefficient of choride Diffusion in Plain, Silica, and Fly ash cement concrete, Jurnal of testing and evaluation, 
[4] J. Wongpa et al (2010)," Compressive Strength, modulus of Elasticity, and water permeability of Inorganic Polimer Concrete", Journal Materials and Desain Elsevier

[5] Kartini et al,(2010), “Absorption and permeability Performance of Selangor Rice Huk Ash Blended Grade 30 Concrete, Journal of Engineering Science and technology. 